\title{
Corneal transplantation and immunosuppressants
}

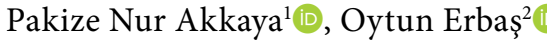 \\ ${ }^{1}$ Department of Histology and Embryology, Balıesir University Faculty of Medicine, Balıkesir, Turkey \\ ${ }^{2}$ Department of Physiology, Demiroğlu Bilim University Faculty of Medicine, Istanbul, Turkey
}

\begin{abstract}
Corneal graft is the most common and most transplanted tissue due to its immune privilege. After corneal transplantation, topical or systemic immunosuppression is applied depending on the patient's case and condition. Immunosuppressants are a group of drugs that suppress the body's immune system and prevent organ rejection by preventing the transplanted organs from being perceived as foreign by the body and stimulating the body's natural immunity. Immunosuppressants are subdivided into corticosteroids, calcineurin inhibitors, interleukin 2 receptor blockers, and mTOR inhibitors. Inflammation or corneal vascularization in the transplant recipient increases the risk of graft rejection and affects the success of transplantation. To prevent rejection, systemic immunosuppressants are used in high-risk transplantation patients, however, long-term immunosuppressants have low efficacy and severe side effects, making it difficult to manage this process. Patient-specific immunomodulation therapy is currently thought to be the most effective treatment for the high-risk transplantation group. In this review, the characteristics, effects, and efficacy of topical and systemic immunosuppressants used in the post-transplantation period are described in scope of the possibility of corneal graft rejection after transplantation and according to the immune privilege of cornea and risk factors for corneal transplantation. Novel immunoregulators and cellular therapies that may increase the success of corneal transplantation without side effects of immunosuppressants are also emphasized.

Keywords: Cornea transplant, graft rejection, immune privilege, immunomodulators, immunosuppressants.
\end{abstract}

\section{CORNEA TRANSPLANT AND IMMUNE PRIVILEGE}

Keratoplasty, more commonly known as "cornea transplant", is the replacement of the cornea layer of an eye that has lost its transparency due to various cornea degenerations or dystrophias with the cornea of a healthy donor. For this, usually under general anesthesia, a 6-9 mm wide circular region is removed from the patient's cornea and the healthy cornea from the donor is sewn into place.

The idea of cornea transplantation was first presented by Pellier De Quengsi in 1789. ${ }^{[1]}$ The first successful keratoplasty was performed in 1905 by Eduard Konrad Zirm. Zirm successfully performed a penetrant keratoplasty on a 45-year-old patient with cornea defect caused by chemical burn. ${ }^{[2]}$ In 1935, use of cadaver eyes for transplant was conceived, expediting developments in keratoplasty. ${ }^{[3]}$

The first keratoplasty in Turkey was conducted in 1937 at the Istanbul University Medical Faculty Department of Ophthalmology by Prof. Dr. Igersheimer. ${ }^{[4]}$ Research and progress on techniques and preservation of donor cornea continues. ${ }^{[5]}$

A normal and healthy cornea is absent of blood and lymph vessels; this creates an "immune privilege" specific to the cornea. ${ }^{[6]}$ Due to this privilege, corneal transplantations can be performed in patients without high risk with 90\% success rate in the first year after transplant and $55 \%$ in the first 15 years. ${ }^{[7,8]}$

The microenvironment of the eye structurally possesses both immunosuppressant and antiinflammatory properties. This immunosuppression 
formed by ocular cells and tissues in the eye is referred to as "immune privilege". Immune privilege helps prevent against the severe damage generated by infiltration of inflammatory cells. ${ }^{[9]}$ To date, the immunosuppressive mechanism described in the eye consists of the microenvironment containing ocular fluids, the blood-retinal barrier, and ocular parenchymal cells. Ocular fluids such as aqueous humor and vitreous fluids have anti-inflammatory properties. ${ }^{[10,11]}$ Production of regulatory $\mathrm{T}$ cells (Treg) also play a role in composing the immunotolerance of the eye. ${ }^{[12]}$ Corneal epithelial cells and the retinal pigment epithelium (RPE) also contribute to the formation of an immune barrier with tight junctions. In addition, RPE cells structurally express immunosuppressive molecules and release immunomodulator factors which can provide mediation in an immunogenic environment. ${ }^{[13,16]}$ Due to these unique immune circumstances in the cornea, cornea transplants are more successful and do not require systemic immunosuppression under normal circumstances, in contrast to other organ transplantations. It is true that the cornea is a tissue with "immune privilege" because of its structural properties and microenvironment, however, this should not be mistaken with "immune immunity" as the presence of lymphatic channels have been shown in vascularized corneas. In Changes in normal distribution of antigens and immune reactive cells have been shown in conditions such as inflammation, scarring, and vascularization in the cornea, leading to increase in number of type 2 antigen-bearing bone marrow-derived dendritic cells. ${ }^{[17-21]}$

\section{CORNEAL GRAFT REJECTION}

Loss of maintaining transparency after transplantation may occur due to two reasons: immune graft rejection (allograft rejection) and non-immune graft failure. The main risk factors for allograft rejection include: HLA incompatibility between the donor and receiver, use of grafts larger than $8 \mathrm{~mm}$, and vascularization that develops in the donor cornea. Among these risk factors, corneal vascularization plays the greatest role. A study by Hill[22] revealed that the outcome of regraft in avascular graft with immune-induced rejection was no different from primary grafts, but that increased corneal vascularization significantly increased risk of rejection. Another study showed that using large grafts was associated with increased amount of HLA antigen which may increase the rate of rejection reactions. ${ }^{[23]}$ According to studies by the CCTS (Collaborative Corneal Transplantation Studies), risk factors for graft rejection in corneal transplantations included: previous corneal transplantation surgery, formation and degree of stromal vascularization, glaucoma before operation, young age of the recipient, previous anterior segment operations, degree of anterior synechia, history of chemical burn, and incompatibility between donor and recipient blood groups. The study by Medawar and Bilingham ${ }^{[38]}$ demonstrated the role of HLA antigen incompatibility between the donor and recipient in graft rejection. Previous corneal transplantation surgery earned antigenic sensitivity and increased the response to the newly transplanted tissue. ${ }^{[2]}$ In children, immune reactions are more severe and rejection reactions are more frequent, therefore penetrant keratoplasty success is also affected by recipient age. ${ }^{[25,26]}$ In addition, transplantation patients with known ocular allergies recorded during routine clinical examinations were found to have higher risk of corneal allograft rejection. ${ }^{[27,28]}$ In a study conducted by Hau et al., ${ }^{[29]}$ corneal leukocyte density was examined in vivo after corneal transplantation and it was shown that increased leukocyte concentrations in the endothelium could be associated with severe graft rejection.

Corneal graft rejection was first described as "Malaide du Greffon" (Greffon's disease) in 1949 by Paufique, Sourdille and Offret. ${ }^{[30]}$ Immunologic origin of this condition was first proposed by Edward Maumenee in the 1950s. ${ }^{[18]}$ One of four graft recipients have experienced at least one rejection attack; $20 \%$ of these attacks are irreversible and cause transplantation failure. ${ }^{[31]}$ Half of graft rejection cases occur in the first three months of the postoperative period, while 90\% occur within the first year. Late graft rejection reactions are seen in 10\% of cases and they develop 1-15 years after surgery. ${ }^{[32]}$

Studies by researchers including Khoda-Doust and Silverian indicated that since the cornea is an avascular tissue, immune response may be suppressed, however, graft rejection may occur especially in the endothelial layer in patients with vascularization. ${ }^{[30]}$ Therefore, the appearance of a line formed by the accumulation of inflammatory 
cells on the endothelial surface of the cornea is called the "Khodadoust line" (rejection line). ${ }^{[33]}$ Corneal graft rejection is characterized by rejection lines, reactions of the anterior and vitreous infiltrations in the subepithelial space or keratic precipitates in the endothelium, and stromal edema. ${ }^{[34,35]}$

Development of neovascularization and inflammation during placement of the healthy cornea is considered "high risk" for corneal transplantation rejection. Because it causes chronic inflammation, eyes with herpetic, interstitial, or traumatic keratitis sequalae have increased vascularization, increasing the incidence of graft rejection. ${ }^{[23]}$ There are three main factors that contribute to corneal allograft vitality: prevention of the induction of immune reaction against allograft antigens, production of regulatory $\mathrm{T}$ cells (Treg) that can suppress destructive alloimmune reaction, and activation of apoptosis of inflammatory cells in the graft/recipient interface. ${ }^{[36]}$ Strategies used to prevent graft rejection include: antigen alteration, determining HLA compatibility, use of UV light, hyperbaric oxygen application, and immunosuppressive drug therapies.

\section{IMMUNOSUPPRESSANTS TO SUPPRESS IMMUNE RESPONSES}

One of the strategies used to prevent graft rejection is the use of immunosuppressive agents such as corticosteroids, cyclosporine $\mathrm{A}$, tacrolimus, mycophenolate mycotil, and rapamycin. In addition, new immunomodulatory approaches are currently being developed for high-risk corneal transplantations. One of these approaches is the inhibition of corneal angiogenesis by suppressing VEGF. ${ }^{[37]}$ Studies have shown that topical treatment with specific antibodies, trap proteins, or receptor antagonists prevents graft rejection. ${ }^{[38,39]}$ Also using gene therapies, inhibition of potential immunoreactivity in the recipient by reducing antigen presenting cells (APCs) in the donor cornea and subsequently the number of antigens transferred to the recipient is also an objective. ${ }^{[40]}$

Corneal transplantations that are not vascularized and do not develop inflammation are considered "low risk" for graft rejection and these cases do not require any systemic immunosuppression or HLA-compatibility. High-risk corneal transplantations, however, have less than 35\% survival in the first five years after transplantation, despite the use of immunosuppressives. ${ }^{[41-43]}$ This data is known to be even worse than numbers from kidney, liver, or heart transplantations. ${ }^{[4]}$

In recipients that carry high risk for graft rejection, neovascularization causes invasion of blood and lymph vessels into the corneal graft. This allows transport of immune effector cells to the graft through new corneal vessels, inducing immune reaction and graft rejection. ${ }^{[45]}$ Many studies have demonstrated that as neovascularization advances, immune alloantigenic response increases. ${ }^{[46,47]}$ Khodadoust and Silverstein ${ }^{[48]}$ reported that $65 \%$ of heavily vascularized corneas developed graft rejection and transplantation resulted in failure despite intense immunosuppression.

Prophylactic immunosuppressive treatments following transplantation are determined according to the patient's degree of risk. Use of topical steroids in the low risk group has been proven to increase transplant success. ${ }^{[49]}$ However, there are different protocols in the length of using topical corticosteroids. ${ }^{[50]}$ The most commonly preferred method is the topical use of $1 \%$ prednisolone acetate preparations initially for four times daily and after three months once daily for a period of 12 months. In case of signs of rejection reactions frequency of application must be switched to once hourly. ${ }^{[51]}$ New surgical techniques have been used to reduce the amount of allogeneic tissue in the transplanted graft and to prevent the transfer of endothelial cells to the recipient. ${ }^{[52]}$ Nevertheless, such approaches have not achieved the desired degree of positive impact on the high-risk group..$^{[1]}$ Interestingly enough, according to the American Cornea Society, endothelial keratoplasty patients encountered less graft rejection compared to penetrant keratoplasty patients. ${ }^{[50,53]}$

According to the results of the Collaborative Corneal Transplantation Studies (CCTS), aside from these approaches, immunosuppressants, especially topical corticosteroids, have always played a key role in inhibiting immunological pathways to suppress graft rejection. ${ }^{[54]}$

As in low risk corneal transplantations, corticosteroids are also used as the first-line for prophylactic treatment in high-risk groups. 1\% prednisolone or $0.1 \%$ dexamethasone drops are 
applied 6-8 times daily. Although length of use varies depending on the surgeon, according to studies by the Cornea Society, treatment continues for an average of eight months. ${ }^{[50]}$

Systemic immunosuppressants are used as the basis for prophylactic treatment in high-risk patient groups; however, there is no definite margin or provision on this matter as it usually depends on the surgeon's evaluation and judgement. This makes it difficult to compare studies and results. Along with their effects in preventing graft rejection, systemic immunosuppressants may also cause ocular side effects such as glaucoma, infection, and potentially life-threatening systemic side effects. ${ }^{[55-57]}$ The main purpose of immunosuppression is to prevent rejection in the recipient by pharmacologically developing a specific tolerance towards the graft.

Corticosteroids play a key role in the approach to the corneal transplantation process. They prevent proliferation, chemotaxis, and neovascularization of $\mathrm{T}$ cells. Studies on animal models have demonstrated that in the case of high risk of graft vascularization, topical steroid use delayed passage of vessels through graft margins, increasing graft vitality. ${ }^{[51]}$ They can be used before, during, or after transplantation. They can be used alone, or in combination with other immunosuppressive agents in the case of acute graft rejection. ${ }^{[58,59]}$ According to the study by the American Cornea Society, oral prednisolone (40-80 mg/day and for 2-7 days) in addition to topical steroids is almost always used as a prophylactic treatment by $22 \%$ of surgeons in high-risk patients; apart from this, it is applied as prophylactic treatment when corneal graft rejection occurs. ${ }^{[60,61]}$

In animal model studies by Kim et al., ${ }^{[62]}$ corticosteroid use was initiated two weeks before corneal transplantation, and they succeeded in reducing corneal neovascularization. Supportive of this finding, there are studies that show that initiation of preoperative corticosteroids reduces angiogenesis in both low- and high-risk patient groups. ${ }^{[57]}$

Surgeons have leaned towards use of singledose intravenous corticosteroid use in addition to topical steroids in $14 \%$ of high-risk cases. In this sense, single-dose $125 \mathrm{mg}$ intravenous methylprednisolone in addition to hourly application of topical steroid treatment was shown to significantly prevent severe graft rejection in the high-risk patient group. ${ }^{[63]}$ Another study indicated that single-dose $500 \mathrm{mg}$ intravenous methylprednisolone treatment was as effective as oral corticosteroid treatment in preventing endothelial rejection and emphasized that it also provided the advantage of preserving the patient against the systemic side effects caused by longterm oral corticosteroid use. ${ }^{[64,65]}$ A study by Hill et al. ${ }^{[65]}$ reported that intravenous administration achieved 79\% and oral therapy achieved 63\% success in terms of corneal graft survival, while corneal graft rejection was observed in 25\% of intravenously treated patients, and $67 \%$ in recipients receiving oral therapy. Crouzet et al.[66] experiment on rabbits that underwent penetrant keratoplasty, in which corneal vascularization and graft rejection rate was significantly reduced when dexamethasone implants were placed in the subconjunctiva compared to the placebo group; this rate was found to be significantly similar to subjects receiving Dexamethasone in drop form as an immunosuppressant after corneal transplantation.

According to results published by the American Cornea Society in 2011, use of postoperative subconjunctival methylprednisolone injection, oral prednisolone use, and intravenous methylprednisolone and corticosteroid applications was reported to be increasing in corneal transplantations; when these treatment regimens were compared, subconjunctival steroid applications were found to be more effective in low-risk corneal transplantation groups with $76 \%$ success rate. In the high-risk group, the success rate of these applications remained at $57 \% .{ }^{[50]}$ The main factors limiting the application of corticosteroid treatment are its systemic toxic effects and increased ocular pressure in long-term use, formation of subcapsular cataracts, risks of infection development, delayed wound healing, and systemic pathologies such as Cushing's syndrome. ${ }^{[67,68]}$

Azathioprine: Although it is commonly used as a systemic immunosuppressant in solid organ transplantations and bone marrow transplantation, its use in cornea transplantation is limited. It prevents proliferation by changing DNA and RNA structure in cells with rapid proliferation. They are mostly used together with corticosteroids; in 
some cases, administration together with both corticosteroids and cyclosporine is available. ${ }^{[51]}$

Cyclosporin A (CsA) is a strong immunosuppressant effective against $T$ cell function. Cyclosporin $\mathrm{A}$ is an 11 amino acid peptide isolated from the Tolypocladium inflatum fungus. It inhibits nuclear factor activation by playing a role in the production of intracellular protein of cyclophilin, which inhibits calcineurin enzyme activation. ${ }^{[67]}$ By inhibiting the IL-2 pathway, it prevents the synthesis and release of proinflammatory cytokines including IL-2, IL-4, interferon gamma (IFN- $\gamma$ ), and tumor necrosis factor-alpha (TNF- $\alpha)$. Therefore, it blocks differentiation of cytotoxic and helper T cells. ${ }^{[69]}$ On the other hand, it is thought that it does not affect B lymphocyte functions. It prevents lymphocyte migration to the graft and is relatively effective in preventing rejection. While it is used in autoimmune diseases and to prevent immune rejection after many solid organ transplantations, high doses or long-term oral or intravenous use is known to cause side effects such as hypertension, nephrotoxicity, hepatotoxicity, gastrointestinal toxicity, gingival hyperplasia, fainting, paresthesia, hypersensitivity to heat, elevated blood urea and creatinine values and rarely lymphoma. ${ }^{[56,70,71]}$

Cyclosporin A has been used in both oral and topical treatment in ophthalmology. Its topical treatment is especially preferred in order to avoid systemic side effects and to administer greater amount of drug to the eye and has been used by ophthalmologists for the treatment of various immune system diseases such as dry eye disease, atopic keratoconjunctivitis, Behçet's disease and ocular graft-versus-host disease. ${ }^{[95,96]}$ Both topical and oral forms are used to prevent graft rejection in cornea transplantations. Although outcomes of its oral use seem to have reached a definite consensus, a study by Hill[55] showed that graft rejection occurred in $49 \%$ of the group who received CsA treatment after cornea transplantation compared to $73 \%$ in the group who was not administered CsA. Researchers have also proposed that longer periods of CsA use such as 12 months would be more effective rather than short periods such as 4-6 months and that length of use was positively associated with success rates in preventing graft rejection. ${ }^{[74]}$ Gürelik et al. ${ }^{[75]}$ conducted a study on CsA use in high-risk penetrant keratoplasty cases and reported that the use of CsA at the latest one week after the operation had a positive effect on the prognosis and that the use of CsA did not change the prognosis more than one month later. In contrast, other studies containing high-risk corneal transplantation groups revealed the effect of CsA was limited or even unsuccessful. ${ }^{[56,76]}$ Shimazaki et al. ${ }^{[77]}$ suggested that there was no significant difference between the treatment group and the control group in terms of the success of preventing graft rejection (rates 30-16\%), even in the systemic use of CsA, and that graft rejection was also seen in patients who were initially successful with discontinuation of treatment. Another prospective randomized study by Reinhardt et al. ${ }^{[78]}$ did not find a significant difference between oral CsA and oral mycophenolate mofetil after corneal transplantation. Inadequate success of oral CsA following corneal transplantation in the high-risk group was associated with inability of CsA to adequately reach aqueous humor despite high levels in serum and therefore lack of ability to maintain immune privilege. ${ }^{[77]}$

Tacrolimus (FK506) is an antibiotic isolated from Streptomyces tsukubaensis. It is a calcineurin inhibitor with effect similar to CsA. Due to its mechanism of action, it inhibits $\mathrm{T}$ cell activation and therefore T-lymphocute signal transmission and IL-2 transcription. In addition, it may also suppress release of TNF- $\alpha$, IFN- $\gamma$, and other cytokines. ${ }^{[79]}$ Although 25-100 times more effective than $\mathrm{CsA}$, it has been reported to cause less side effects in areas such as inducing hypertension or causing dysfunction in lipid metabolism. ${ }^{[80]}$

Tacrolimus is used for treatment of immune ophthalmologic diseases such as keratoconjunctivitis, posterior uveitis, and chronic graft-versus-host disease and also as an immunosuppressant in high-risk corneal transplantation cases. Daily $(2-12 \mathrm{mg})$ use of systemic Tacrolimus in the high-risk group was shown to significantly decrease graft rejection and increase graft vitality by $65 \%$ in high corneal transplantation. ${ }^{[81]}$ Although daily dosage was found as $1-12 \mathrm{mg}$, there is no definite information about its ideal length of use. ${ }^{[82]}$ Its most common side effect is hypertension (23\%) and other side effects include headache, fatigue, and gastrointestinal disturbances. ${ }^{[81]}$ 
Yamazoe et al. ${ }^{[83]}$ reported significantly less corneal rejection and longer graft vitality in patients administered $10-20 \mathrm{ng} / \mathrm{mL}$ dose Tacrolimus compared to patients undergoing CsA treatment following transplantation. In addition, patients treated with Tacrolimus had better tolerance compared to those treated with CsA.

Mycophenolate mofetil (MMF) works by inhibiting de novo synthesis of guanosine nucleotides and as a result, inhibiting $\mathrm{T}$ and $\mathrm{B}$ lymphocyte proliferation. ${ }^{[84]}$ Its most common side effects include infections, anemia, leukopenia, and gastrointestinal disorders. In ophthalmology, it is used in the treatment of uveitis and high-risk corneal transplantations. ${ }^{[67,78]}$ Reinhard et al. ${ }^{[85]}$ conducted a prospective study on 86 transplant patients and reported that immune reaction did not develop in $89 \%$ of the group that was administered MMF compared to $67 \%$ in the control group. Both patient groups were applied topical corticosteroids for five months postoperatively. Mycophenolate mofetil is a relatively well tolerated immunosuppressant.

In terms of effectiveness and side effects, there are several studies that compare MMF and CsA. Reis et al. ${ }^{[86]}$ conducted a prospective study on 41 patients and reported that there was no significant difference between MMF an CsA in terms of success in preventing tissue rejection (10\% vs. $9.5 \%)$ and that side effects were observed in both groups at the end of the 10 month period. The authors also reported similar success levels between MMF and CsA used in combination with oral corticosteroids following acute tissue rejection in high-risk corneal transplantation cases.

In the study by Reinhard et al., ${ }^{[78]}$ cases were investigated postoperatively for three years and found no significant difference between MMF and $\mathrm{CsA}$ in terms of preventing graft rejection (74\% vs. 69\%). In a retrospective study of 417 high-risk transplantation patients by Birnbaum et al., ${ }^{[67]}$ MMF was significantly more successful in preventing graft rejection compared to CsA with a rate of 72 to $60 \%$, but no significant difference was found in terms of graft vitality $(87 \%$ vs. $77 \%)$. The same study reported that there were fewer side effects in patients treated with MMF compared to those treated with CsA.

Rapamycin (Sirolimus) is a bacterial macrolide isolated from Streptomyces hygroscopicus with antifungal and immunosuppressive properties. It consists of FK-binding protein complex (FKBP-12) and inhibits mTOR. ${ }^{[87]}$ Despite its similar structure to tacrolimus, since it is not a calcineurin inhibitor, it has no nephrotoxic effect. It reduces T-lymphocyte activation induced by IL-2. ${ }^{[88]}$ Rapamycin is also used in solid organ transplantations since it inhibits proliferation of growth factor originated fibroblasts, endothelial cells, and smooth muscles cells.

A prospective study conducted by Birnbaum et al. ${ }^{[89]}$ compared the outcomes of Rapamycin or MMF treatment in the postoperative period of corneal transplantation. At the end of six months, it was reported that there were no immune reactions in either group, however, in the second postoperative year, only two patients developed reversible immune reaction in the Rapamycin group. Chatel and Larkin ${ }^{[90]}$ reported various side effects including arterial thrombosis associated with rapamycin treatment following high risk corneal transplantation and they suggested that its use should be limited to "safe doses".

\section{NEW APPROACHES IN IMMUNE THERAPIES}

These studies aim to develop new strategies to increase corneal vitality success by conducting experiments on animal models. One rat keratoplasty model succeeded in suppressing APCs with malononitrilamide (FK778) maturation. ${ }^{[91]}$ Various experimental animal models have also shown that antibody-based treatment agents decreased or delayed tissue rejection in vascularized organ allografts. ${ }^{[92]}$ There are ongoing studies on polyclonal, monoclonal, and recombinant antibodies or their combined versions to target IL-1 blockage, leukocyte function antigen-1 (LFA-1), VLA-1 (very late antigen-1), VLA-4, CD40-CD154 pathway, and immune cells such as CD28 and CD3, as well as the suppression of molecules effecting these targets. Experimental studies have shown Cytotoxic T Lymphocyte Antigen 4 (CTLA4-Ig) protein inhibits $\mathrm{T}$ cell activation and increased corneal allograft success. ${ }^{[93]}$ Nevertheless, use of antibody therapies as immunosuppressants is limited in humans due to systemic side effects and risks of anti-idiotypic/anti-isotypic antibody development 
in the transplant recipient. ${ }^{[94]}$ In addition, due to the structure of the eye, injected antibodies have high likelihood of being transferred into the eye, which is why only a fraction of these studies have passed into their clinical phase.

Studies on cellular treatments for immunosuppression have demonstrated significantly high levels of Foxp3 levels in corneal allograft recipients who developed rejection, suggesting that Treg dysfunction plays a major role in allograft rejection. ${ }^{[95]}$ Another study stated that administration of systemic IL-2 treatment in mice with high risk of rejection increased effectiveness and suppression level of Treg cells, reduced leukocyte infiltration in the graft, and improved corneal allograft vitality. It is hoped that new studies on this subject will contribute to further understanding of the function and mechanisms of Tregs to apply Treg-based treatments to increase success of corneal transplantation, even in corneas with vascularization or inflammation. ${ }^{[96]}$

Today, there are ongoing studies on new approaches to keep alloimmunity under control, focusing on morpholine oligonucleotides, cell-specific gene therapy, RNA interaction, anti-VEGF therapy, thrombogenic APC and IL-2 therapy. ${ }^{[97]}$

\section{Declaration of conflicting interests}

The authors declared no conflicts of interest with respect to the authorship and/or publication of this article.

\section{Funding}

The authors received no financial support for the research and/or authorship of this article.

\section{REFERENCES}

1. Rintelelen R. Zur geschichte der keratoplastik. Klin Monatsbl Augenheild. Surgical Ophthalmology 1974;165:214-22.

2. Özdemir Ö. Keratoplasti Tipleri, Donör göz kaynakları, göz bankacılığı. Ankara: VI. Ulusal Oftalmoloji Kursu; 1986. s. 63.

3. Mannis MJ, Krachmer JH. Keratoplasty: a historical perspective. Surv Ophthalmol 1981;25:333-8.

4. Yazar N. Keratoplasti komplikasyonları. [Uzmanlık Tezi], İstanbul: İstanbul Üniversitesi Tip Fakültesi; 1965.

5. Sürel Z. Gelişmekte olan ülkelerde keratoplasti, medikolegal sorunlar. Ankara: VI Ulusal Oftalmoloji Kursu; 1986. s:137-143.

6. Chauhan SK, Dohlman TH, Dana R. Corneal lymphatics: role in ocular inflammation as inducer and responder of adaptive immunity. J Clin Cell Immunol 2014;5. pii: 1000256.

7. Williams KA, Coster DJ. The immunobiology of corneal transplantation. Transplantation 2007;84:806-13.

8. Sangwan VS, Ramamurthy B, Shah U, Garg P, Sridhar MS, Rao GN. Outcome of corneal transplant rejection: a 10-year study. Clin Exp Ophthalmol 2005;33:623-7.

9. Streilein JW. Ocular immune privilege: therapeutic opportunities from an experiment of nature. Nat Rev Immunol 2003;3:879-89.

10. Streilein JW, Ksander BR, Taylor AW. Immune deviation in relation to ocular immune privilege. $\mathrm{J}$ Immunol 1997;158:3557-60.

11. Taylor AW. Ocular immunosuppressive microenvironment. Chem Immunol Allergy. 2007;92:71-85.

12. Streilein JW. Ocular immune privilege: therapeutic opportunities from an experiment of nature. Nat Rev Immunol 2003;3:879-89

13. Sugita S. Role of ocular pigment epithelial cells in immune privilege. Arch Immunol Ther Exp (Warsz) 2009;57:263-8.

14. Ma W, Wong WT. Aging Changes in Retinal Microglia and their Relevance to Age-related Retinal Disease. Adv Exp Med Biol 2016;854:73-8.

15. Chinnery HR, McMenamin PG, Dando SJ. Macrophage physiology in the eye. Pflugers Arch 2017;469:501-15.

16. Mochizuki M, Sugita S, Kamoi K. Immunological homeostasis of the eye. Prog Retin Eye Res 2013;33:10-27.

17. Sakaguchi S, Yamaguchi T, Nomura T, Ono M. Regulatory $\mathrm{T}$ cells and immune tolerance. Cell. 2008;133:775-87.

18. Özdemir Ö, Gündüz K. Grefon reddi. MN Oftalmoloji Kontakt lens özel sayısı. 1996;3:79-83.

19. Brightbill FS. Corneal Surgery: theory, technique and tissue. 4th ed. St. Louis: Mosby; 1993.

20. Prendergast DG, Easty DL. Immunological aspects of corneal graft rejection. Immunol Lett 1991;29:73-6.

21. De la Maza MS. Immunoregulation, immunofolerance, autoimmunity, and immune Privilege. In: Albert DM, Jakobiec FA, editors. Principles and Practice of Ophtalmology. Philadelphia: W.B. Saunders Company; 1994. p. 785-99.

22. Hill JC. The relative importance of risk factors used to define high-risk keratoplasty. Ger J Ophthalmol 1996;5:36-41.

23. Boisjoly HM, Bernard PM, Dubé I, Laughrea PA, Bazin R, Bernier J. Effect of factors unrelated to tissue matching on corneal transplant endothelial rejection. Am J Ophthalmol 1989;107:647-54.

24. Fine M, Stein M. The role of corneal vascularization in human cornea graft reactions. In: Corneal Graft Failure. Amsterdam: Elsevier; 1973. p. 193-204. 
25. Alldredge OC, Krachmer JH. Clinical types of corneal transplant rejection. Their manifestations, frequency, preoperative correlates, and treatment. Arch Ophthalmol 1981;99:599-604.

26. Cowden JW. Penetrating keratoplasty in infants and children. Ophthalmology 1990;97:324-8.

27. Ghoraishi M, Akova YA, Tugal-Tutkun I, Foster CS. Penetrating keratoplasty in atopic keratoconjunctivitis. Cornea 1995;14:610-3.

28. Hargrave S, Chu Y, Mendelblatt D, Mayhew E, Niederkorn J. Preliminary findings in corneal allograft rejection in patients with keratoconus. Am J Ophthalmol 2003;135:452-60.

29. Hau S, Clarke B, Thaung C, Larkin DFP. Longitudinal changes in corneal leucocyte density in vivo following transplantation. Br J Ophthalmol 2019;103:1035-41.

30. Mader TH, Stulting RD. The high risk penetrating keratoplasty. Ophthalmology Clinics of North America 1991;4:411-26.

31. Stulting RD, Waring GO 3rd, Bridges WZ, Cavanagh HD. Effect of donor epithelium on corneal transplant survival. Ophthalmology 1988;95:803-12.

32. İrkeç M. Kornea immünolojisi ve grefon hastalığ1. In: Turaçlı ME, editor. Tensen Oft. Kursu (kornea cerrahisi) Bülteni. Ankara: Öztek Ofset 1986. s. 119123.

33. Khodadoust AA, Silverstein AM. Transplantation and rejection of individual cell layers of the cornea. Invest Ophthalmol 1969;8:180-95.

34. Kramer SG. Penetrating keratoplasty combined with extracapsular cataract extraction. Am J Ophthalmol 1985;100:129-33.

35. Meyer RF, Musch DC. Assessment of success and complications of triple procedure surgery. Am J Ophthalmol 1987;104:233-40.

36. Cunnusamy K, Paunicka K, Reyes N, Yang W, Chen PW, Niederkorn JY. Two different regulatory $\mathrm{T}$ cell populations that promote corneal allograft survival. Invest Ophthalmol Vis Sci 2010;51:6566-74.

37. Dastjerdi MH, Saban DR, Okanobo A, Nallasamy N, Sadrai Z, Chauhan SK, et al. Effects of topical and subconjunctival bevacizumab in high-risk corneal transplant survival. Invest Ophthalmol Vis Sci 2010;51:2411-7.

38. Bock F, Maruyama K, Regenfuss B, Hos D, Steven $\mathrm{P}$, Heindl LM, et al. Novel anti(lymph)angiogenic treatment strategies for corneal and ocular surface diseases. Prog Retin Eye Res 2013;34:89-124.

39. Dohlman TH, Di Zazzo A, Omoto M, Hua J, Ding J, Hamrah P, et al. E-Selectin Mediates Immune Cell Trafficking in Corneal Transplantation. Transplantation 2016;100:772-80.

40. Zhang X, Shen L, Jin Y, Saban DR, Chauhan SK, Dana R. Depletion of passenger leukocytes from corneal grafts: an effective means of promoting transplant survival? Invest Ophthalmol Vis Sci 2009;50:3137-44.

41. Dana MR, Qian Y, Hamrah P. Twenty-five-year panorama of corneal immunology: emerging concepts in the immunopathogenesis of microbial keratitis, peripheral ulcerative keratitis, and corneal transplant rejection. Cornea 2000;19:625-43.

42. Lam H, Dana MR. Corneal graft rejection. Int Ophthalmol Clin 2009;49:31-41.

43. Zhu SN, Yamada J, Streilein JW, Dana MR. ICAM1 deficiency suppresses host allosensitization and rejection of $\mathrm{MHC}$-disparate corneal transplants. Transplantation 2000;69:1008-13.

44. Qazi Y, Hamrah P. Corneal Allograft Rejection: Immunopathogenesis to Therapeutics. J Clin Cell Immunol 2013;2013(Suppl 9). pii: 006.

45. Cursiefen C, Cao J, Chen L, Liu Y, Maruyama $\mathrm{K}$, Jackson $\mathrm{D}$, et al. Inhibition of hemangiogenesis and lymphangiogenesis after normal-risk corneal transplantation by neutralizing VEGF promotes graft survival. Invest Ophthalmol Vis Sci 2004;45:2666-73.

46. Williams KA, Roder D, Esterman A, Muehlberg SM, Coster DJ. Factors predictive of corneal graft survival. Report from the Australian Corneal Graft Registry. Ophthalmology 1992;99:403-14.

47. Maguire MG, Stark WJ, Gottsch JD, Stulting RD, Sugar A, Fink NE, et al. Risk factors for corneal graft failure and rejection in the collaborative corneal transplantation studies. Collaborative Corneal Transplantation Studies Research Group. Ophthalmology 1994;101:1536-47.

48. Khodadoust AA, Silverstein AM. Studies on the nature of the privilege enjoyed by corneal allografts. Invest Ophthalmol 1972;11:137-48.

49. Dua HS, Azuara-Blanco A. Corneal allograft rejection: risk factors, diagnosis, prevention, and treatment. Indian J Ophthalmol 1999;47:3-9.

50. Kharod-Dholakia B, Randleman JB, Bromley JG, Stulting RD. Prevention and treatment of corneal graft rejection: current practice patterns of the Cornea Society (2011). Cornea 2015;34:609-14.

51. Han DC, Mehta JS, Por YM, Htoon HM, Tan DT. Comparison of outcomes of lamellar keratoplasty and penetrating keratoplasty in keratoconus. Am J Ophthalmol 2009;148:744-51.

52. Coster DJ. Mechanisms of corneal graft failure: the erosion of corneal privilege. Eye (Lond) 1989;3:251-62.

53. Anshu A, Price MO, Price FW Jr. Risk of corneal transplant rejection significantly reduced with Descemet's membrane endothelial keratoplasty. Ophthalmology 2012;119:536-40.

54. The collaborative corneal transplantation studies (CCTS). Effectiveness of histocompatibility matching in high-risk corneal transplantation. The Collaborative Corneal Transplantation Studies Research Group. Arch Ophthalmol 1992;110:1392-403.

55. Hill JC. Systemic cyclosporine in high-risk keratoplasty: long-term results. Eye (Lond) 1995;9:422-8.

56. Poon AC, Forbes JE, Dart JK, Subramaniam S, Bunce C, Madison P, et al. Systemic cyclosporin A in high risk penetrating keratoplasties: a case-control study. Br J Ophthalmol 2001;85:1464-9. 
57. Uchiyama E, Papaliodis GN, Lobo AM, Sobrin L. Side-effects of anti-inflammatory therapy in uveitis. Semin Ophthalmol 2014;29:456-67.

58. Randleman JB, Stulting RD. Prevention and treatment of corneal graft rejection: current practice patterns (2004). Cornea 2006 ;25:286-90.

59. Rapuano CJ, Cohen EJ, Brady SE, Arentsen JJ, Laibson PR. Indications for and outcomes of repeat penetrating keratoplasty. Am J Ophthalmol 1990 ;109:689-95.

60. Abudou M, Wu T, Evans JR, Chen X. Immunosuppressants for the prophylaxis of corneal graft rejection after penetrating keratoplasty. Cochrane Database Syst Rev 2015:CD007603.

61. Shimazaki J, Iseda A, Satake Y, Shimazaki-Den S. Efficacy and safety of long-term corticosteroid eye drops after penetrating keratoplasty: a prospective, randomized, clinical trial. Ophthalmology 2012;119:668-73.

62. Kim HK, Choi JA, Uehara H, Zhang X, Ambati BK, Cho YK. Presurgical corticosteroid treatment improves corneal transplant survival in mice. Cornea 2013;32:1591-8.

63. Braude LS, Chandler JW. Corneal allograft rejection. The role of the major histocompatibility complex. Surv Ophthalmol 1983;27:290-305.

64. Hill JC, Maske R, Watson P. Corticosteroids in corneal graft rejection. Oral versus single pulse therapy. Ophthalmology 1991;98:329-33.

65. Hill JC, Maske R, Watson PG. The use of a single pulse of intravenous methylprednisolone in the treatment of corneal graft rejection. A preliminary report. Eye (Lond) 1991;5 :420-4.

66. Crouzet E, Garcin T, Gauthier AS, He Z, Perrache $\mathrm{C}$, Delavenne $\mathrm{X}$, et al. Immunosuppression by a subconjunctival implant releasing dexamethasone in a rabbit model of penetrating keratoplasty. $\mathrm{Br} \mathrm{J}$ Ophthalmol 2018;102:692-9.

67. Birnbaum F, Böhringer D, Sokolovska Y, Sundmacher $\mathrm{R}$, Reinhard T. Immunosuppression with cyclosporine $\mathrm{A}$ and mycophenolate mofetil after penetrating highrisk keratoplasty: a retrospective study. Transplantation 2005;79:964-8.

68. Costa DC, de Castro RS, Kara-Jose N. Case-control study of subconjunctival triamcinolone acetonide injection vs intravenous methylprednisolone pulse in the treatment of endothelial corneal allograft rejection. Eye (Lond) 2009;23:708-14.

69. Taylor AL, Watson CJ, Bradley JA. Immunosuppressive agents in solid organ transplantation: Mechanisms of action and therapeutic efficacy. Crit Rev Oncol Hematol 2005;56:23-46.

70. Calne RY. Cyclosporin in cadaveric renal transplantation: 5-year follow-up of a multicentre trial. Lancet 1987;2:506-7.

71. Greenberg A, Thompson ME, Griffith BJ, Hardesty RL, Kormos RL, el-Shahawy MA, et al. Cyclosporine nephrotoxicity in cardiac allograft patients--a seven- year follow-up. Transplantation 1990;50:589-93.

72. Dastjerdi MH, Hamrah P, Dana R. High-frequency topical cyclosporine $0.05 \%$ in the treatment of severe dry eye refractory to twice-daily regimen. Cornea 2009;28:1091-6.

73. Wan KH, Chen LJ, Rong SS, Pang CP, Young AL. Topical cyclosporine in the treatment of allergic conjunctivitis: a meta-analysis. Ophthalmology 2013;120:2197-203.

74. Hill JC. Systemic cyclosporine in high-risk keratoplasty. Short- versus long-term therapy. Ophthalmology 1994;101:128-33.

75. Gürelik G, Akata F, Öz Ö, Öz Y, Sarıcaoğlu S, Yllmazbaş $\mathrm{P}$, et al. Yüksek risk parsiyel penetran keratoplasti olgularında cyclosporin A. 28. Ulusal Oftalmoloji Kongresi, 1994. Antalya: Kongre Bülteni; 1994. s. 886-7.

76. Inoue K, Kimura C, Amano S, Sato T, Fujita N, Kagaya $\mathrm{F}$, et al. Long-term outcome of systemic cyclosporine treatment following penetrating keratoplasty. Jpn J Ophthalmol 2001;45:378-82.

77. Shimazaki J, Den S, Omoto M, Satake Y, Shimmura $\mathrm{S}$, Tsubota K. Prospective, randomized study of the efficacy of systemic cyclosporine in high-risk corneal transplantation. Am J Ophthalmol 2011;152:33-9.

78. Reinhard T, Reis A, Böhringer D, Malinowski M, Voiculescu A, Heering P, et al. Systemic mycophenolate mofetil in comparison with systemic cyclosporin A in high-risk keratoplasty patients: 3 years' results of a randomized prospective clinical trial. Graefes Arch Clin Exp Ophthalmol 2001;239:367-72.

79. Tamura K, Fujimura T, Iwasaki K, Sakuma S, Fujitsu T, Nakamura K, et al. Interaction of tacrolimus(FK506) and its metabolites with FKBP and calcineurin. Biochem Biophys Res Commun 1994;202:437-43.

80. Friemann S, Feuring E, Padberg W, Ernst W. Improvement of nephrotoxicity, hypertension, and lipid metabolism after conversion of kidney transplant recipients from cyclosporine to tacrolimus. Transplant Proc 1998;30:1240-2.

81. Joseph A, Raj D, Shanmuganathan V, Powell RJ, Dua HS. Tacrolimus immunosuppression in high-risk corneal grafts. Br J Ophthalmol. 2007;91:51-5.

82. Sloper CM, Powell RJ, Dua HS. Tacrolimus (FK506) in the management of high-risk corneal and limbal grafts. Ophthalmology 2001;108:1838-44.

83. Yamazoe K, Yamazoe K, Yamaguchi T, Omoto M, Shimazaki J. Efficacy and safety of systemic tacrolimus in high-risk penetrating keratoplasty after graft failure with systemic cyclosporine. Cornea 2014;33:1157-63.

84. Allison AC, Eugui EM. Mechanisms of action of mycophenolate mofetil in preventing acute and chronic allograft rejection. Transplantation 2005;80:S181-90.

85. Reinhard T, Mayweg S, Sokolovska Y, Seitz B, Mittelviefhaus H, Engelmann K, et al. Systemic mycophenolate mofetil avoids immune reactions in penetrating high-risk keratoplasty: preliminary results 
of an ongoing prospectively randomized multicentre study. Transpl Int 2005; 18:703-8.

86. Reis A, Reinhard T, Voiculescu A, Kutkuhn B, Godehardt E, Spelsberg H, et al. Mycophenolate mofetil versus cyclosporin $A$ in high risk keratoplasty patients: a prospectively randomised clinical trial. $\mathrm{Br}$ J Ophthalmol 1999;83:1268-71.

87. Oshiro N, Yoshino K, Hidayat S, Tokunaga C, Hara K, Eguchi S, et al. Dissociation of raptor from $m T O R$ is a mechanism of rapamycininduced inhibition of mTOR function. Genes Cells 2004;9:359-66.

88. Wiederrecht GJ, Sabers CJ, Brunn GJ, Martin MM, Dumont FJ, Abraham RT. Mechanism of action of rapamycin: new insights into the regulation of G1-phase progression in eukaryotic cells. Prog Cell Cycle Res 1995;1:53-71.

89. Birnbaum F, Reis A, Böhringer D, Sokolowska Y, Mayer K, Voiculescu A, et al. An open prospective pilot study on the use of rapamycin after penetrating high-risk keratoplasty. Transplantation 2006;81:767-72.

90. Chatel MA, Larkin DF. Sirolimus and mycophenolate as combination prophylaxis in corneal transplant recipients at high rejection risk. Am $\mathrm{J}$ Ophthalmol 2010;150:179-84.

91. Birnbaum F, Schwartzkopff J, Scholz C, Reis A, Reinhard T. The new malononitrilamide immunosuppressant FK778 prolongs corneal allograft survival in the rat keratoplasty model. Eye (Lond) 2007;21:1516-23.

92. Asai T, Choi BK, Kwon PM, Kim WY, Kim JD, Vinay DS, et al. Blockade of the 4-1BB (CD137)/4$1 \mathrm{BBL}$ and/or CD28/CD80/CD86 costimulatory pathways promotes corneal allograft survival in mice. Immunology 2007;121:349-58.

93. Comer RM, King WJ, Ardjomand N, Theoharis S, George AJ, Larkin DF. Effect of administration of CTLA4-Ig as protein or cDNA on corneal allograft survival. Invest Ophthalmol Vis Sci 2002;43:1095-103.

94. Hori J, Isobe M, Yamagami S, Mizuochi T, Tsuru T. Specific immunosuppression of corneal allograft rejection by combination of anti-VLA-4 and antiLFA-1 monoclonal antibodies in mice. Exp Eye Res 1997;65:89-98.

95. Chauhan SK, Saban DR, Lee HK, Dana R. Levels of Foxp3 in regulatory $\mathrm{T}$ cells reflect their functional status in transplantation. J Immunol 2009;182:14853.

96. Tahvildari M, Omoto M, Chen Y, Emami-Naeini P, Inomata $\mathrm{T}$, Dohlman $\mathrm{TH}$, et al. In Vivo Expansion of Regulatory $\mathrm{T}$ Cells by Low-Dose Interleukin-2 Treatment Increases Allograft Survival in Corneal Transplantation. Transplantation 2016;100:525-32.

97. Abud TB, Di Zazzo A, Kheirkhah A, Dana R. Systemic Immunomodulatory Strategies in Highrisk Corneal Transplantation. J Ophthalmic Vis Res 2017;12:81-92. 